\title{
Effectiveness of Zinc Coated, Blended and Bio-Activated Zinc Coated Urea to Quality, Biochemical Parameters and Yield in Rice Crop(Oryza sativa L.)
}

\author{
Qudsia Nazir1, Muhammad Aftab ${ }^{1 *}$, Ghulam Sarwar², Aneela Riaz ${ }^{3}$, Sarfraz Hussain ${ }^{1}$, Ifra Saleem ${ }^{1}$, \\ Amina Kalsom ${ }^{1}$, Noor-Us-Sabah ${ }^{2}$, Mukkram Ali Tahir ${ }^{2}$, Ateeq-ur-Rehman ${ }^{4}$ and Muhammad Arif ${ }^{1}$
}

${ }^{1}$ Institute of Soil Chemistry and Environmental Sciences, AARI, Faisalabad, Pakistan; ${ }^{2}$ Department of Soil and Environmental Sciences, College of Agriculture, University of Sargodha, Pakistan; ${ }^{3}$ Soil Bacteriology Section, Agri. Biotechnology Research Institute AARI, Faisalabad, Pakistan; ${ }^{4}$ Pakistan National Accreditation Council, Islamabad, Pakistan.

Abstract | Zinc $(\mathrm{Zn})$ is an important microelement not only for animals, plants but for humans as well. Its importance cannot ignore for the plants to improve overall quality and yield. The overall physiology, quality and biochemical parameters also enhanced with optimum application of $\mathrm{Zn}$. By keeping in mind, the facts, it was hypothesized that the use of $\mathrm{ZnO}$ (a cheap source of $\mathrm{Zn}$ ) impregnated urea for rice may enhance grains (paddy) yield. Three types of urea were prepared including $\mathrm{Zn}$ coated, bio-activated $\mathrm{Zn}$ coated and $\mathrm{Zn}$ blended urea at the $1.5 \%$ rate of formulate. The bio-activated $Z n$ coated urea was prepared by inoculating the powdered organic material with Zinc solubilizing bacterium and then this material was mixed with $\mathrm{ZnO}$. This bio-active $\mathrm{Zn}$ was coated on urea at $1.5 \%$ rates to formulate. Moreover, $\mathrm{Zn}$ blended urea was prepared by mixing powder $\mathrm{ZnO}$ with urea. The comparative efficacies of different types of $\mathrm{Zn}$ impregnated urea were compared with $\mathrm{ZnSO}_{4}$ to grains yield, physiology and biochemistry of rice under field conditions. The results showed that $1.5 \%$ bio-activated $\mathrm{Zn}(\mathrm{ZnO})$ coated urea performed better in promoting yield and biochemical parameters. About 15 to $20 \%$ increase was observed in yield physical, biochemical and quality parameters. This suggests that the application of bio-activated $\mathrm{Zn}$ coated urea @ 1.5\% is greatly active in enhancing quality and yield of rice crop.

Received | May 11, 2020; Accepted | March 28, 2021; Published | June 22, 2021

*Correspondence | Muhammad Aftab, Institute of Soil Chemistry and Environmental Sciences, AARI, Faisalabad, Pakistan; Email: m.aftabjee@gmail.com

Citation | Nazir, Q., M. Aftab, G. Sarwar, A. Riaz, S. Hussain, I. Saleem, A. Kalsom, N.U. Sabah, M.A. Tahir, A. Rehman and M. Arif. 2021. Effectiveness of zinc coated, blended and bio-activated zinc coated urea to quality, biochemical parameters and yield in rice crop (Oryza sativa L.). Pakistan Journal of Agricultural Research, 34(3): 524-532.

DOI | https://dx.doi.org/10.17582/journal.pjar/2021/34.3.524.532

Keywords | Zinc, Urea, Quality, Rice, Bio-activated Zn, Yield

\section{Introduction}

$\mathrm{M}$ illions of people in the world feeding on cereals like wheat and rice $(\mathrm{FAO}, 2012)$. After wheat, rice is utmost imperative essential crop of Pakistan. It contributes approximately 0.6 percent in GDP. During 2018-2019 rice was sown on 2810 thousand hectares with production of 7202 thousand tons
(Pakistan Economic Survey, 2018-2019). World's population increasing day by day, therefore, food need is also increasing, while the natural resources are same (United Nations, 2012). Malnutrition is a very popular issue of poor communities and due to reduced bioavailability, micronutrients deficiency is also becoming serious issue (Huang et al., 2002). In the soils of $\mathrm{Zinc}(\mathrm{Zn})$ deficient areas, $\mathrm{Zn}$ deficiency 
in humans consider fifth largest reason of deaths (WHO, 2002). Almost 8 to $11 \mathrm{mg}$ per day $\mathrm{Zn}$ is required for adults daily while pregnant and lactating mothers require more consumption that is about 12 $\mathrm{mg} /$ day (Palanog et al., 2019). Insufficiency of zinc leads to problems of respiration, diarrhea and malaria in many developing countries. Normal reproductive system, immune system, cell growth effects due to $\mathrm{Zn}$ deficiency in humans (WHO, 2002). Almost $37 \%$ of Pakistani population is suffering in $\mathrm{Zn}$ malnutrition (UNDP, 2003). Zinc application to soil enhances growth and yield of plants and recovers overall vigor and plant pigments e.g., sugars and oil contents, over all $\mathrm{Zn}$ also improves physiological, bio-chemical and quality of cereals (Khalifa et al., 2011). The possible solution to overcome this problem of low $\mathrm{Zn}$ contents in crops is the use of fertilizers but due to economic issues of farmers and fixation of zinc fertilizers in calcareous soils, its usage is not adopted by farmers. By keeping in mind, the importance of $\mathrm{Zn}$ for plants and humans, strategies must be employed to increase Zn bioavailability.

As in Pakistan, soils are deficient in $\mathrm{Zn}$ because soils having more $\mathrm{CaCO}_{3}$ contents and less organic matter, high soil pH (Hafeez et al., 2013) and high soil phosphorous contents (Singh et al., 1986). Due to $\mathrm{Zn}$ deficient soils the crop grown on such soils are also $\mathrm{Zn}$ deficient. The people of such poor countries suffer from severe $Z n$ deficiency. To address this issue, so many techniques are in use like clinical treatment of nutrients, biofortication and bioavailability of nutrients etc. (Mayer, 2008). Biofortification of zinc is in practice by so many methods, i.e., genetic breeding and agronomic methods. At the same time, balanced fertilizers management is too a common means used by farmers in the country. Zinc is being used in the form of $\mathrm{ZnSO}_{4}$. Another alternate source of zinc is $\mathrm{ZnO}$ but its high price is not permitting farmers to apply it in the field. This insoluble $\mathrm{Zn}$ can be solubilizing by ZSB (Zinc solubilizing bacteria). An experiment was conducted in field on rice crop to check the influence of $\mathrm{ZnO}$ coated, blended and bioactivated $\mathrm{Zn}$ coated urea on physiological, quality, biochemical and rice growth.

\section{Materials and Methods}

Rice crop was transplanted under field conditions on research area of University of Agriculture, Faisalabad and comparative effectiveness of $\mathrm{Zn}$ blended,
$\mathrm{Zn}$ coated and bio-activated $\mathrm{Zn}$ coated urea was evaluated for physiological, quality and bio-chemical parameters under field conditions for rice crop (Cultivar: Shaheen).

\section{Physico-chemical characteristics of soil}

Soil samples were taken randomly from various sites of field and samples were spreaded and dried in the air. All samples were passed through sieve having mesh size of $2 \mathrm{~mm}$ after grinding. Method suggested by Moodie et al. (1959) was used to determine soil textural class that was sandy clay loam. All laboratory analysis was accomplished applying methods of Handbook No. 60 of USDA (1969) or otherwise referred. Total nitrogen and available phosphorus in soil was determined according to methods of Jackson (1962) and Watanabe and Olsen (1965), respectively. Likewise, concentration of zinc in plant samples was determined by using method of Soltanpour and Workman (1979).

\section{Preparation of $1.5 \% \mathrm{Zn}$ coated, Bio-activated Zn coated and $\mathrm{Zn}$ blended urea}

Pre-isolated $\mathrm{Zn}$ solubilizing bacterial strain Bacillus sp. AZ6 (accession number KT221633) (Hussain et al., 2015) was taken University of Agriculture, Faisalabad, Pakistan. Zinc solubilizing bacteria were isolated from rhizosphere of maize plants using dilution plate method and agar medium (Hussain et al., 2015)). Inoculum of the strain AZ6 was made by rising it in $1000 \mathrm{~mL}$ flask having Bunt and Rivera basal medium (Bunt and Rovira, 1955). Glass flasks used for inoculation purpose were incubated at temperature of $28 \pm 10^{\circ} \mathrm{C}$ for total time of 72 hours on an incubator of orbital shaking type. Before use, an optical density of 0.5 at $535 \mathrm{~nm}$ was adjusted. Mixture of bacteria so prepared was utilized for the formulation of zinc coated urea. The powder organic material (plant residues) was first dried in an oven at $800^{\circ} \mathrm{C}$. It was inoculated with bacterial strain AZ6 and incubated for $72 \mathrm{~h}$ at $30 \pm 20^{\circ} \mathrm{C}$ in an incubator. Then this bio-augmented organic material was thoroughly mixed with $300-400$ mesh size $\mathrm{ZnO}$ in the ratio of 40:60 (powder $\mathrm{ZnO}$ : bio-augmented organic material). This mixture was again incubated for 3 days at $30 \pm 20^{\circ} \mathrm{C}$ to attain extreme chelation of zinc through organic complexes. The bio-active $\mathrm{Zn}$ was coated on urea at $1.5 \%$ rates to formulate bio-activated Zn coated urea. Before impregnation/ coating on urea granules, the bio-active $\mathrm{Zn}$ complex was once again passed through 300-400 mesh size 
sieves. All the precautions were used and there was no change in the composition of urea. In $\mathrm{Zn}$ coated urea strain AZ6 was not added while in $\mathrm{Zn}$ blended urea $1.5 \% \mathrm{Zn}(\mathrm{ZnO})$ was only mix with urea.

\section{Experimental description}

The field experiment was conducted with six treatments including $\mathrm{T} 0=$ control (no $\mathrm{Zn}$ ), $\mathrm{T} 1=\mathrm{ZnSO}_{4}$ (Recommended), $\mathrm{T} 2=\mathrm{ZSB}$ (Zinc solubilizing bacteria), $\mathrm{T} 3=1.5 \% \mathrm{Zn}$ coated urea, $\mathrm{T} 4=$ $1.5 \%$ bio-activated $\mathrm{Zn}$ coated urea, $\mathrm{T} 5=1.5 \% \mathrm{Zn}$ blended urea, each treatment was repeated thrice. NPK recommended (180, 115 and $90 \mathrm{~kg} \mathrm{ha}^{-1}$ ) was applied from urea, di-ammonium phosphate (DAP) and sulfate of potash (SOP). Zinc @ $5 \mathrm{~kg} \mathrm{ha}^{-1}$ was applied. At maturity, rice plants were harvested. Data regarding different growth parameters were noted.

\section{Physiological parameters}

Photosynthetic rate (A), transpiration rate (E), stomatal conductance parameters were measured. In the same way efficiency of water use by rice plants was also noted using CIRAS-3 System. Efficiency of water use was calculated as under:

\section{Water use efficiency $(A / E)=$ Photosynthetic rate $(A) /$ Transpiration rate (E)}

Method of Arnon (1949) was used for the determination of chlorophyll $\mathrm{a}$ and $\mathrm{b}$ and carotenoids. Electrolyte leakage was measured by Lutts et al. (1995) and Carbonic Anhydrase Activity Enzyme was detected by method of Dwivedi and Randhawa (1974).

\section{Quality parameters}

Oil contents were determined by Soxhelt apparatus. Oil contents were as:

\section{Oil \%age $=$ Weight of ether extract $/$ Weight of flour sample $x 100$}

Ash/minerals, dry matter and moisture contents of rice grains were determined by given expressions:

$$
\text { Ash (\%) = weight of reside / weight of sample } x 100
$$

Dry matter (\%) = weight of oven dry sample / weight of sample before drying $x 100$

Moisture (\%) = weight of sample - oven dry weight of sample / weight of sample $\times 100$
Nitrogen content and crude protein from rice grains was determined using methods of Wolf (1982) and Shih et al. (1999), respectively.

\section{Statistical analysis}

Software Statistix 8.1 was used for the analysis of variance of all collected data (Steel et al., 1997).

\section{Results and Discussion}

The applications of $1.5 \%$ bio-activated $\mathrm{Zn}$ coated urea significantly $(P<0.05)$ increased the chlorophyll contents (both $\mathrm{a}$ and $\mathrm{b}$ ) of rice as compared to $1.5 \%$ $\mathrm{Zn}$ coated urea and $4.7 \%$ increase was observed in case of chlorophyll a and $7.3 \%$ in chlorophyll b (Table 1) In case of carotenoids contents $1.5 \%$ bio-activated $\mathrm{Zn}$ coated urea showed maximum results and it was almost $57 \%$ increase as compared to recommended $\mathrm{Zn}\left(\mathrm{ZnSO}_{4}\right)$, while 46 and $31 \%$ increase was observed in stomatal conductance as compared to control and recommended $\mathrm{Zn}\left(\mathrm{ZnSO}_{4}\right)$. It was also found that plants receiving $1.5 \%$ bio-activated $\mathrm{Zn}$ coated urea showed maximum photosynthetic and transpiration rate, the percent increase was 20 and 11.5 , respectively obtained with the application of $1.5 \%$ bio-activated $\mathrm{Zn}$ coated urea as compared to recommended $\mathrm{Zn}$ $\left(\mathrm{ZnSO}_{4}\right)$. Water use efficiency which is the ratio of Photosynthetic and transpiration rate showed statistically significant effect by the application of $\mathrm{Zn}$ in the form of $\mathrm{Zn}$ coated, blended and bio-activated $\mathrm{Zn}$ coated urea All treatments showed statistically significant results as compared to control $(P<0.05)$, while $1.5 \%$ bio-activated $\mathrm{Zn}$ coated urea showed maximum results in case of water use efficiency. Almost similar results were obtained in $1.5 \% \mathrm{Zn}$ blended and $1.5 \% \mathrm{Zn}$ coated urea and there was $27.7 \%$ increase as compared to control. An increase of $18.7 \%$ was noted with the application of $\mathrm{ZSB}$. About $16 \%$ increase was observed with $1.5 \%$ bio-activated $\mathrm{Zn}$ coated urea as compared to $\mathrm{Zn}\left(\mathrm{ZnSO}_{4}\right)$.

In all physiological parameters of rice crop 1 to 15 percent increase was observed with the application of $1.5 \%$ bio-activated $\mathrm{Zn}(\mathrm{ZnO})$ coated urea as compared to recommended $\mathrm{Zn}\left(\mathrm{ZnSO}_{4}\right)$.

Different methods of $\mathrm{Zn}$ application showed statistically significant results $(P<0.05)$ as compared to control where no $\mathrm{Zn}$ was applied (Table 2). Ash contents $(6.7 \%)$ were recorded with the application of $1.5 \%$ bio-activated $\mathrm{Zn}$ coated urea and it was $55 \%$ 
Table 1: Comparative effectiveness of zinc blended, zinc coated and bio-activated zinc coated urea with respect to physiological parameters of rice.

\begin{tabular}{|c|c|c|c|c|c|c|c|c|}
\hline Treatment & $\begin{array}{l}\text { Choloro- } \\
\text { phyll a (mg } \\
\left.\mathbf{g}^{-1}\right)\end{array}$ & $\begin{array}{l}\text { Cholo- } \\
\text { rophyll b } \\
\left(\mathrm{mg} \mathrm{g}^{-1}\right)\end{array}$ & $\begin{array}{l}\text { Caroti- } \\
\text { noides } \\
\left(\mathrm{mg} \mathrm{g}^{-1}\right)\end{array}$ & $\begin{array}{l}\text { Stomatal } \\
\text { conductance } \\
\left(\mu \mathrm{mol}^{-2} \mathrm{~s}^{-1}\right)\end{array}$ & $\begin{array}{l}\text { Sub stoma- } \\
\text { tal } \mathrm{CO}_{2(\mu \mathrm{mol}} \\
\text { mol }\end{array}$ & $\begin{array}{l}\text { Photosyn- } \\
\text { thetic rate } \\
(\mathrm{A})(\mu \mathrm{mol} \\
\left.\mathrm{m}^{-1} \mathrm{~S}^{-1}\right)\end{array}$ & $\begin{array}{l}\text { Transpira- } \\
\text { tion rate }(\mathrm{E}) \\
\left(\mathbf{m m o l} \mathrm{H}_{2} \mathrm{O}\right. \\
\left.\mathbf{m}^{-2} \mathrm{~S}^{-1}\right)\end{array}$ & 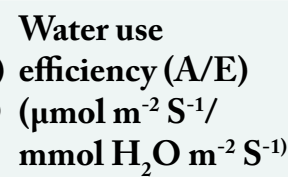 \\
\hline Control & $20.5 \pm 0.45 \mathrm{e}$ & $19 \pm 0.5 \mathrm{e}$ & $0.5 \pm 0.03 \mathrm{~b}$ & $60.6 \pm 0.2 \mathrm{f}$ & $370.4 \pm 29.8 \mathrm{a}$ & $5.4 \pm 0.2 \mathrm{~d}$ & $1.6 \pm 0.2 \mathrm{~b}$ & $2.6 \pm 0.2 \mathrm{c}$ \\
\hline Recommended $\mathrm{Zn}$ & $40.5 \pm 0.2 \mathrm{c}$ & $23.4 \pm 0.6 \mathrm{c}$ & $0.8 \pm 0.05 \mathrm{~b}$ & $88.2 \pm 0.2 \mathrm{~d}$ & $240 \pm 11.5 \mathrm{c}$ & $9.0 \pm 1.2 \mathrm{bc}$ & $2.5 \pm 0.4 \mathrm{a}$ & $3.6 \pm 0.2 \mathrm{~b}$ \\
\hline ZSB & $29 \pm 0.5 \mathrm{~d}$ & $21.4 \pm 0.3 \mathrm{~d}$ & $0.7 \pm 0.2 \mathrm{~b}$ & $76.6 \pm 0.6 \mathrm{e}$ & $336.6 \pm 3.5 \mathrm{~b}$ & $7.7 \pm 0.2 \mathrm{c}$ & $2.3 \pm 0.2 \mathrm{a}$ & $3.2 \pm 0.1 \mathrm{~b}$ \\
\hline $\begin{array}{l}1.5 \% \mathrm{Zn} \text { coated } \\
\text { urea }\end{array}$ & $42.5 \pm 0.5 \mathrm{~b}$ & $24.4 \pm 0.2 \mathrm{~b}$ & $0.9 \pm 0.06 \mathrm{~b}$ & $101.5 \pm 0.3 \mathrm{~b}$ & $199.3 \pm 0.6 \mathrm{~d}$ & $10.2 \pm 0.2 \mathrm{ab}$ & $2.5 \pm 0.3 \mathrm{a}$ & $3.6 \pm 0.06 \mathrm{~b}$ \\
\hline $\begin{array}{l}1.5 \% \text { bioactivated } \\
\mathrm{Zn} \text { coated urea }\end{array}$ & $44.5 \pm 2.5 \mathrm{a}$ & $26.2 \pm 0.2 \mathrm{a}$ & $1.9 \pm 0.2 \mathrm{a}$ & $112.6 \pm 1.7 \mathrm{a}$ & $197 \pm 1.2 \mathrm{~d}$ & $11.2 \pm 0.2 \mathrm{a}$ & $2.6 \pm 0.1 \mathrm{a}$ & $4.3 \pm 0.2 \mathrm{a}$ \\
\hline $\begin{array}{l}1.5 \% \mathrm{Zn} \text { blended } \\
\text { urea }\end{array}$ & $41.5 \pm 0.8 \mathrm{bc}$ & $24.2 \pm 0.1 \mathrm{~b}$ & $0.9 \pm 0.18 \mathrm{~b}$ & $94.5 \pm 0.5 \mathrm{c}$ & $241.3 \pm 0.7 \mathrm{c}$ & $9.4 \pm 0.3 \mathrm{~b}$ & $2.5 \pm 0.1 \mathrm{a}$ & $3.6 \pm 0.3 \mathrm{~b}$ \\
\hline LSD & 1.6350 & 0.3338 & 0.4097 & 0.5088 & 9.9923 & 1.5031 & 0.5181 & 0.4248 \\
\hline
\end{tabular}

Means sharing the same letters within the column do not differ significantly $(P<0.05)$. Values shows mean $\pm S E$.

\section{Quality parameters}

Table 2: Comparative effectiveness of zinc blended, zinc coated and bio-activated zinc coated urea with respect to quality parameters of rice.

\begin{tabular}{|c|c|c|c|c|c|c|}
\hline Treatment & $\begin{array}{l}\text { Ash contents } \\
(\%)\end{array}$ & $\begin{array}{l}\text { Moisture } \\
\text { contents (\%) }\end{array}$ & $\begin{array}{l}\text { Dry matter } \\
\text { contents (\%) }\end{array}$ & $\begin{array}{l}\text { Oil contents } \\
(\%)\end{array}$ & $\begin{array}{l}\text { Protein } \\
\text { contents (\%) }\end{array}$ & $\begin{array}{l}\text { Nitrogen } \\
\text { concentration (\%) }\end{array}$ \\
\hline No Zn & $3 \pm 0.1 \mathrm{~d}$ & $9.2 \pm 0.04 \mathrm{a}$ & $90.6 \pm 0.2 c$ & $0.04 \pm 0.002 c$ & $11.9 \pm 0.6 \mathrm{~b}$ & $1.9 \pm 0.3 \mathrm{c}$ \\
\hline Recommended $\mathrm{Zn}$ & $6 \pm 0.05 \mathrm{a}$ & $6.4 \pm 0.09 \mathrm{~d}$ & $93.4 \pm 1.9 \mathrm{a}$ & $0.07 \pm 0.002 \mathrm{ab}$ & $15 \pm 1.2 \mathrm{a}$ & $2.4 \pm 0.2 \mathrm{ab}$ \\
\hline ZSB & $4 \pm 0.02 c$ & $8.3 \pm 0.2 \mathrm{~b}$ & $91.7 \pm 0.6 \mathrm{bc}$ & $0.05 \pm 0.002 b c$ & $13 \pm 0.6 \mathrm{~b}$ & $2.1 \pm 0.06 \mathrm{bc}$ \\
\hline $1.5 \% \mathrm{Zn}$ coated urea & $6.3 \pm 0.02 \mathrm{a}$ & $7.3 \pm 0.2 \mathrm{c}$ & $92.7 \pm 0.7 \mathrm{ab}$ & $0.08 \pm 0.005 \mathrm{a}$ & $15 \pm 0.3 \mathrm{a}$ & $2.5 \pm 0.3 \mathrm{a}$ \\
\hline $1.5 \%$ bio-activated $\mathrm{Zn}$ coated urea & $6.7 \pm 0.1 \mathrm{a}$ & $6 \pm 0.09 \mathrm{~d}$ & $94 \pm 1.7 \mathrm{a}$ & $0.08 \pm 0.005 \mathrm{a}$ & $15.7 \pm 0.2 \mathrm{a}$ & $2.5 \pm 0.5 \mathrm{a}$ \\
\hline 1.5\% $\mathrm{Zn}$ blended urea & $5 \pm 0.2 b$ & $8.5 \pm 0.3 b$ & $91.5 \pm 0.8 \mathrm{bc}$ & $0.06 \pm 0.006 \mathrm{abc}$ & $15 \pm 0.6 \mathrm{a}$ & $2.4 \pm 0.2 \mathrm{ab}$ \\
\hline LSD & 0.8277 & 0.5448 & 1.5423 & 0.0279 & 1.9102 & 0.3186 \\
\hline
\end{tabular}

Means sharing the same letters within the column do not differ significantly $(P<0.05)$. Values shows mean $\pm S E$.

control where no $\mathrm{Zn}$ was used and minimum in the treatment where $1.5 \%$ bio-activated $\mathrm{Zn}$ coated urea was applied and percent decrease was observed as 34.7\%. Dry matter and oil contents were showed statistically significant effect as compared to control, 3.6 and $50 \%$ increase was observed respectively. While the treatments where ZSB, 1.5\% Zn coated urea, $1.5 \%$ bio-activated $\mathrm{Zn}$ coated urea and $1.5 \%$ $\mathrm{Zn}$ blended urea was applied showed 2.1, 2.4, 2.5 and $2.4 \%$ nitrogen contents respectively. Crude protein was also determined; with the application of $1.5 \%$ bioactivated $\mathrm{Zn}$ coated urea $4.4 \%$ increase as compared to recommended $\mathrm{Zn}\left(\mathrm{ZnSO}_{4}\right)$ was obtained. In all abovementioned quality parameters showed almost 4 to 15 percent increase by the use of $1.5 \%$ bio-activated $\mathrm{Zn}$ $(\mathrm{ZnO})$ coated urea as compared to $\mathrm{Zn}\left(\mathrm{ZnSO}_{4}\right)$.

\section{Biochemical and yield parameters}

Regarding the effect of $\mathrm{Zn}$ application in the form of $\mathrm{Zn}$ coated, $\mathrm{Zn}$ blended, bio-activated $\mathrm{Zn}$ coated urea and ZSB (Bacillus sp.), a statistically significant $(P<0.05)$ results in the electrolyte leakage of rice was recorded (Figure 1). The maximum electrolyte leakage was observed in the control where no $\mathrm{Zn}$ was applied, and minimum value of electrolyte leakage was noted in $1.5 \%$ bio-activated $\mathrm{Zn}$ coated urea. In $1.5 \%$ bio-activated $\mathrm{Zn}$ coated urea $45 \%$ decrease as compare to control was observed. And the results presented in Figure 2 showed that the application of $\mathrm{Zn}$ significantly increased the carbonic anhydrase activity of rice crop as compared to control (no $\mathrm{Zn}$ ). Maximum activity in case of carbonic anhydrase was obtained in the treatment where $1.5 \%$ bio-activated $\mathrm{Zn}$ coated urea was applied (405 umol $\mathrm{CO}_{2} / \mathrm{kg} / \mathrm{s}$ ) and it was 40 and $6.1 \%$ increase as compared to control and recommended $\mathrm{Zn}\left(\mathrm{ZnSO}_{4}\right)$, respectively. Figure 3 clearly showed the statistically significant results $(P<0.05)$ of biomass production $\left(\right.$ tons $\left.\mathrm{ha}^{-1}\right)$ as 
compared to control (no $\mathrm{Zn}$ ). the treatment with $1.5 \%$ bio-activated $\mathrm{Zn}$ coated urea showed $31 \%$ increase as compared to control (no $\mathrm{Zn}$ ). The treatments with 1.5\% $\mathrm{Zn}$ coated and 1.5\% $\mathrm{Zn}$ blended urea was applied showed 14.25 and 14 tons ha $^{-1}$ biomass. With the application of only ZSB (Bacillus sp.) the biomass production was 10.25 tons ha ${ }^{-1}$. Grain's yield (tons ha $\left.{ }^{1}\right)$ of rice is very important parameter in this aspect, the application of $1.5 \%$ bio-activated $\mathrm{Zn}$ coated urea showed maximum results, in this the percent increase was 23.5 as compared to control (no $\mathrm{Zn}$ ) (Figure 4). On the other hand, the treatment with recommended $\mathrm{Zn}\left(\mathrm{ZnSO}_{4}\right)$ and $1.5 \% \mathrm{Zn}$ coated urea showed almost similar results i.e., 4.5 tons $\mathrm{ha}^{-1}$ grains yield. After that the treatment where $1.5 \% \mathrm{Zn}$ blended urea was applied showed 4.3 tons ha ${ }^{-1}$ grains yield of rice. Only $\mathrm{Zn}$ solubilizing bacteria showed 3.6 while control showed 3.5 tons ha $^{-1}$ grains yield of rice. Almost 1.5 $\%$ increase was observed with $1.5 \%$ bio-activated $\mathrm{Zn}$ $(\mathrm{ZnO})$ coated urea as compared to recommended $\mathrm{Zn}$ $\left(\mathrm{ZnSO}_{4}\right)$.

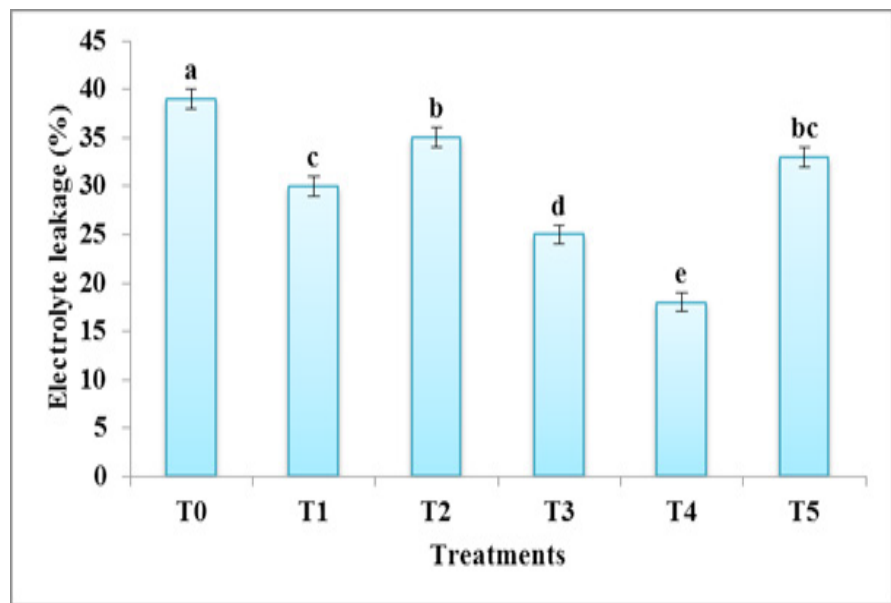

Figure 1: Comparative effectiveness of different $Z n$ treatments on electrolyte leakage of rice. Bar showing the same letters do not differ significantly $(P<0.05)(L S D=3.7579)$.

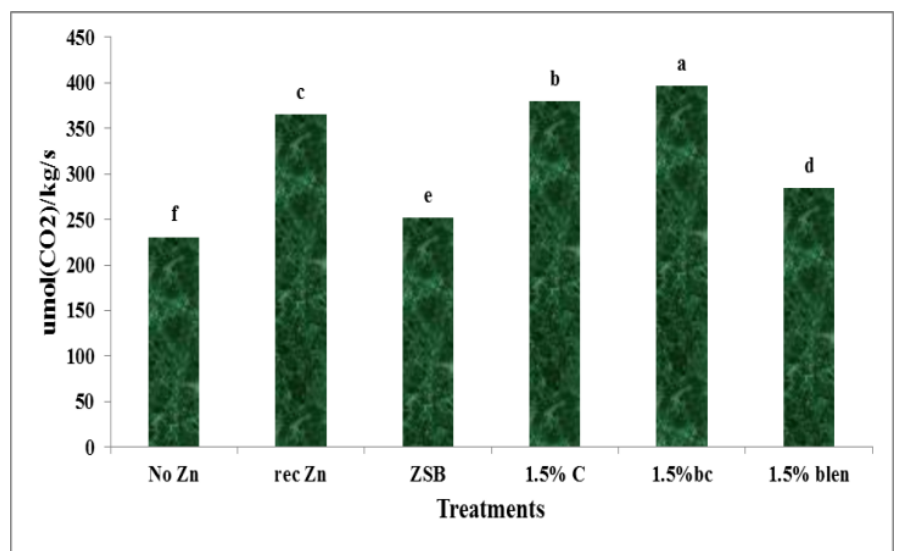

Figure 2: Comparative effectiveness of different $\mathrm{Zn}$ treatments on Carbonic Anbydrase activity of rice Bar showing the same letters do not differ significantly $(P<0.05)$ (LSD=22.771)

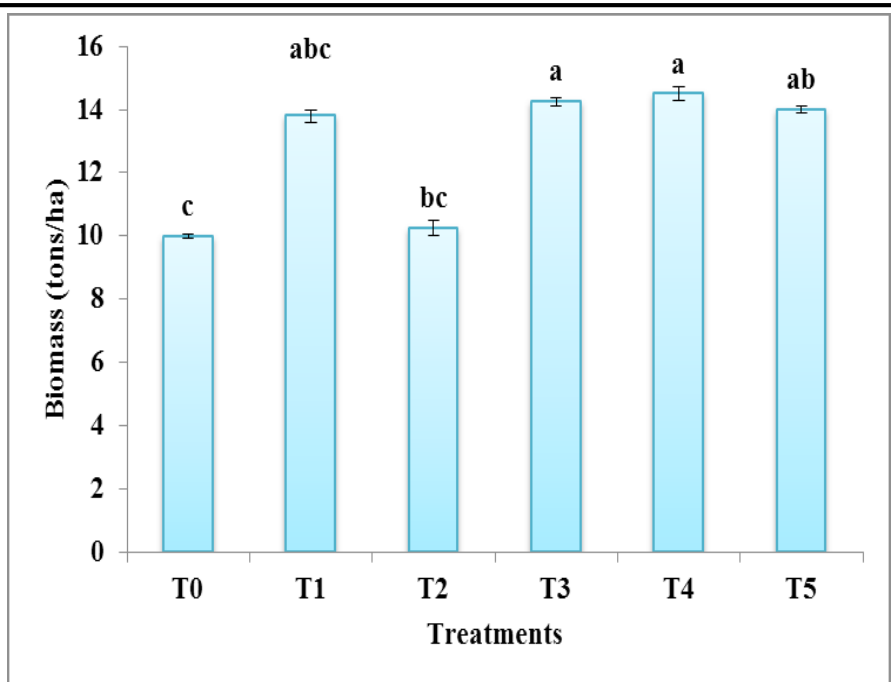

Figure 3: Comparative effectiveness of different $\mathrm{Zn}$ treatments on biomass yield of rice Bar showing the same letters do not differ significantly $(P<0.05)(L S D=0.4243)$.

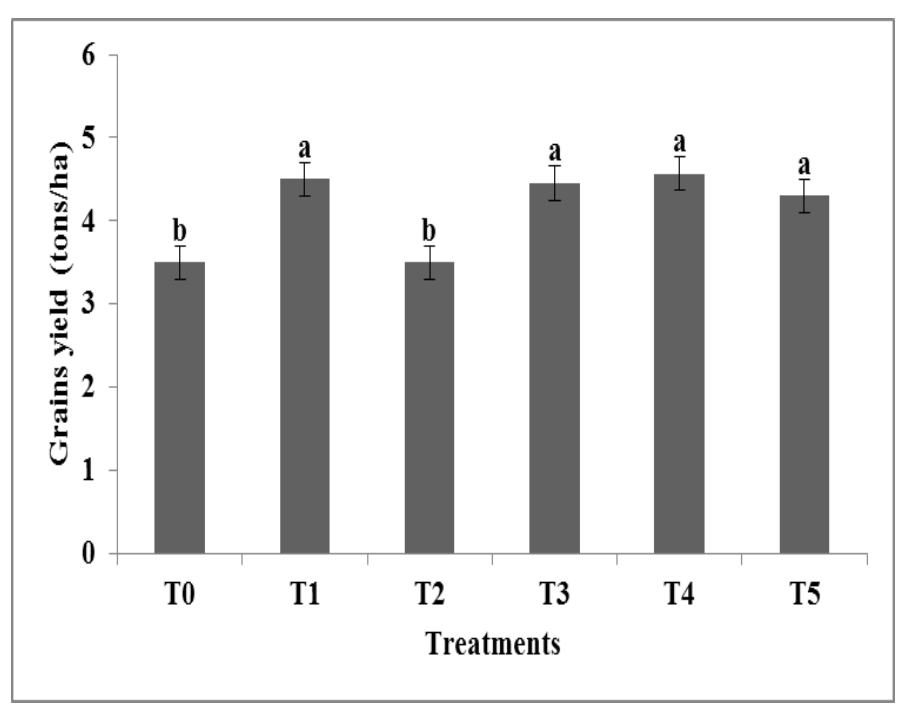

Figure 4: Comparative effectiveness of different $\mathrm{Zn}$ treatments on grains yield of rice Bar showing the same letters do not differ significantly $(P<0.05)(L S D=3.8659$.

Zinc is an essential nutrient required not only for plants but also for humans and microorganisms as well. Humans require $\mathrm{Zn}$ throughout their lives to complete the growth, development and physiological functions (Hambidge and Krebs, 2007). Zinc deficiency ranked as the fourth main micronutrient deficiency in humans, it affects approximately $66 \%$ of the world's population (Zhang et al., 2011). In Pakistan the current practice to overcome the $\mathrm{Zn}$ deficiency is the use of $\mathrm{ZnSO}_{4}$ in soils but its use is problematic for farmers community due to costly and the poor quality available in the market (Shivay et al., 2008). Zinc sulfate contains $33 \% \mathrm{Zn}$ contents while $\mathrm{ZnO}$ has $80 \% \mathrm{Zn}$ but in insoluble form. The effect of $\mathrm{ZnO}$ coating on urea is well documented on growth and yield attributes as compared to the use of $\mathrm{Zn}$ instead 
of coating in rice wheat cropping system. The coated fertilizers such as $\mathrm{Zn}$ coated urea have direct contact with plant roots and enhance nutrient availability by reducing its adsorption on clay complexes (Shivay et al., 2008). The application of PGPR ( $\mathrm{Zn}$ solubilizes) to improve growth and crop yield is an emerging trend in contemporary agriculture in the near future. In the same way bio-activation of $\mathrm{Zn}$ insoluble source i.e., $\mathrm{ZnO}$ and then coating of this bio-activated $\mathrm{Zn}$ $(\mathrm{ZnO})$ on urea also preferred for enhancing $\mathrm{Zn}$ bio-availability in soil and for achieving the purpose of bio-fortification of $\mathrm{Zn}$.

A field experiment was conducted to find out the comparative effectiveness of zinc blended, zinc coated and bio-activated zinc coated urea to physiological, quality, biochemical parameters and yield in Rice (Oryza sativa L.). For the purpose of bio-activation, pre-isolated and identified bacterial strain (Bacillus Sp. AZ6) was used. It is well reported in many previous studies that the application of ZSB in cereals affects the overall growth, yield and grains $\mathrm{Zn}$ concentration, because of having the ability to produce the organic acids and many other mechanisms to solubilize the insoluble sources of $\mathrm{Zn}$ such as $\mathrm{ZnO}$ and $\mathrm{ZnCO}_{3}$ (Saravanan et al., 2003). Prasad and his coworkers reported in 2013 (Prasad et al., 2013) that the major benefit of $Z n$ coated urea is saving in the amount of $Z n$ to be applied, only $2.83 \mathrm{~kg} \mathrm{Zn} \mathrm{ha}^{-1}$ was applied with $\mathrm{Zn}$ coated urea as against $6 \mathrm{~kg} \mathrm{Zn} \mathrm{ha}{ }^{-1}$ in the case of soil + foliar application of $\mathrm{ZnSO} 4$. The $\mathrm{Zn}$ coated urea is therefore a favorable fertilizer in developing countries with small holding farmers (Shivay et al., 2015). In rice crop all physiological parameters were improved with application of bio-activated $\mathrm{Zn}$ coated urea. The physiological parameters such as in enzymes especially carbonic anhydrase (CA) activity in which $\mathrm{Zn}$ act as cofactor improves significantly with the application of $\mathrm{Zn}$ in $\mathrm{Zn}$ deficient soils especially in rice cultivated areas (Reed and Graham, 1980). Carbonic anhydrase activity decreases in many plants as a concern of $\mathrm{Zn}$ deficit conditions (Gibson and Leece, 1981); CA activity is directly related with the $\mathrm{Zn}$ concentration in plants. In severe $\mathrm{Zn}$ deficient conditions, no activity of CA was observed (Guliev et al., 1992). For more activity of $\mathrm{CA}$ in the mesophyll cells, $\mathrm{Zn}$ application is necessary. The activity of $\mathrm{CA}$ is an indicator for the levels of physiologically active $\mathrm{Zn}$ (Gibson and Leece, 1981). The gaseous exchange characteristics such as photosynthetic rate, respiration rate, stomatal and sunstomatal conductance were improved by bio- activated $\mathrm{Zn}$ coated urea. This increase in physiological parameters due to the increase in CA activity. In fact, $\mathrm{CA}$ fixes the $\mathrm{CO}_{2}$ for photosynthesis. The increased rate of photosynthesis automatically increased the all other physiological parameters and biomass of crops, the above-mentioned parameters improved only due to increase in $\mathrm{Zn}$ concentration (Escudero-Almanza et al., 2012). The used ZSB having the ability to produce Auxin and as auxin is the reason to increase the root growth of plants, ultimately increase the nutrients uptake (Kamilova et al., 2006). Membrane permeability and electrolyte leakage effects badly due to $\mathrm{Zn}$ deficiencies. It is the direct indication of membrane permeability. With the application of $\mathrm{Zn}$ the decrease value of electrolyte leakage was observed but maximum reduction in electrolyte leakage was observed in the plot which receives $1.5 \%$ bio-activated Zn coated urea (Welch, 1995). the quality parameters like proteins, nitrogen concentration in grains, oil, ash and dry matter contents in rice and wheat were evaluated and it was observed that these parameters also improved significantly with the application of $\mathrm{Zn}$ and maximum increase was observed with $1.5 \%$ bio-activated $\mathrm{Zn}$ coated urea (Table 2), these results showed similar findings by Seadh et al. (2009); and Soleymani et al. (2009). Increase in quality parameters is just due to the contribution of $\mathrm{Zn}$ in photosynthesis, chlorophyll, starch metabolism of starch enzyme carbonic anhydrase activity and formation, carbohydrate formation, the requirement of $\mathrm{Zn}$ depends upon the above-mentioned processes in plants. It also starts glutamic dehydrogenase activity, RNA and DNA synthesis which are main protein components of gluten accumulated in the later stages of grain filling (Singh et al., 2012; Soleymani et al., 2009). As $\mathrm{N}$ and $\mathrm{Zn}$ have synergistic effect so, with the proper application of $\mathrm{Zn}$ improved $\mathrm{N}$ concentration in grains were obtained (Rehman et al., 2002). The dry matter (\%) increases and moisture (\%) decreases with $\mathrm{Zn}$ fertilization and these results are in agreement with the Sowokinos and Preston, (1988). The oil contents in the cereals also increases with the application of proper $\mathrm{Zn}$ (Ikenie et al., 2004). The yield parameters such as grain yield and biomass production increased significantly with the application of $\mathrm{Zn}$ and improved results were obtained with $1.5 \%$ bio-activated $\mathrm{Zn}$ coated urea (Sadras, 2007). Grain's production is an important parameter contributing towards yield, with the application of $\mathrm{Zn}$ a significant effect on grain yield in rice was observed. But according to some scientists in the recent released 
varieties due to having more yield potential and dilution effect the overall minerals contents becomes low (Zhao et al., 2009), due to dilution effect the starchy grain endosperm enhances in size and becomes rich in minerals as compared to other parts. Many direct and indirect mechanisms are involved to improve the micronutrients availability, root growth improvement is one of the main mechanisms (Khalid et al., 2004). Due to increase in root growth the nutrients availability also increases and over all plant vigor and root-shoot growth enhances. As in grains the $\mathrm{Zn}$ concentration increases, this might be due to the $\mathrm{pH}$ reduction in rhizosphere, reduction in rhizospeheric $\mathrm{pH}$ increases the micronutrients availability to plants (Yu et al., 2011). This reduction in $\mathrm{pH}$ is due to the organic acids produced by the ZSB used for the bio-activation process. Zinc application is necessary for the proper yield of cereals.

\section{Conclusions and Recommendations}

Zinc application in the form of $1.5 \%$ bio-activated $\mathrm{Zn}(\mathrm{ZnO})$ coated urea has a significant effect on physiological, quality, biochemical and yield parameters of rice crop. The grains yield (tons/ha) also enhance in this way. The use of $\mathrm{Zn}$ and urea separately increases the labor cost but with the use of this strategy of coating the extra labor cost and farmers ignorance to $\mathrm{Zn}$ use can be minimized. $\mathrm{ZnO}$ contains more $\mathrm{Zn}$ contents as compare to other $\mathrm{Zn}$ sources. Bio-activation of the insoluble $\mathrm{Zn}$ contents makes it soluble and easily available for plants. The bio-activation by ZSB and then coating on the urea is an environmentally friendly approach and the purpose of improving quality of grains also achieved successfully in rice. This approach of $\mathrm{Zn}$ supply to plants is novel due to eco-friendly, less costly and less time consuming as compared to the others. The farmers of poor community can get maximum benefit by bio-activated $\mathrm{Zn}(\mathrm{ZnO})$ coated urea from their limited resources. It can be concluded that for the cereals grown on the $\mathrm{Zn}$ deficient sites $1.5 \%$ bioactivated $\mathrm{Zn}(\mathrm{ZnO})$ coated urea is effective not only for the increase the yield of cereals grains but also improves grains quality.

\section{Acknowledgements}

I acknowledge Institute of Soil and Environmental Sciences, University of Agriculture, FaisalabadPakistan and Institute of Soil Chemistry and
Environmental Sciences, AARI, Faisalabad-Pakistan to provide facilities to do this research.

\section{Novelty Statement}

Zinc coated urea is effective for cereals under $\mathrm{Zn}$ deficient soils

\section{Author's Contribution}

Qudsia Nazir: Conception and design of work and conduction of experiment

Muhammad Aftab: Interpretation of data and excel work for graphs making

Ghulam Sarwar: Overall supervision and guidance about manuscript write up

Aneela Riaz: Interpretation of data and excel work for graphs making

Sarfraz Hussain: Final editing and proof reading Ifra Saleem and Amina Kalsom: Helped in lab. work Noor-us-Sabah: Elaborated results and discussion Mukkram Ali Tahir: Participated in materials and methodology portion

Ateeq-ur-Rehman: Participated in introduction portion

Muhammad Arif: Statistical analysis of data

\section{Conflict of interest}

The authors have declared no conflict of interest.

\section{References}

AACC, 2000. Approved Methods of American Association of Cereal Chemists, 10 $0^{\text {th }}$ (Ed.) Paul, Minnesota, USA.

Arnon, D.I., 1949. Copper enzymes in isolated chloroplast. Polyphenoloxidases in Beta vulgaris. Plant Physiol., 24: 1-15. https://doi. org/10.1104/pp.24.1.1

Bunt, J.S. and A.D. Rovira. 1955. Microbiological studies of some subantartic soils. J. Soil Sci., 6: 119-128. https://doi. org/10.1111/j.1365-2389.1955.tb00836.x

Dwivedi, R.S. and N.S. Randhawa. 1974. Evaluation of rapid test for hidden hunger of zinc in plants. Plant Soil, 40: 45-451. https:// doi.org/10.1007/BF00011531

Escudero-Almanza, D.J.,D.L. Ojeda-Barrios, O.A. Hernandez-Rodiriguez, E.S. Chavez, T. RuizAnchondo and Sida-Arreola. 2012. Carbonic 
anhydrase and zinc in plant physiology. Chilean J. Agric. Res., 72: 140-146. https://doi. org/10.4067/S0718-58392012000100022

FAO, 2012. Food supply database 2007. Food and Agriculture Organization. Online at http:// faostat.fao.org/site/609/default.aspx\#ancor. Accessed on June 1, 2012.

Gibson, T.S. and D.R. Leece. 1981. Estimation of physiologically active zinc in maize by biochemical assay. Plant Soil, 146: 241-250.

Guliev, N.M., S.H.M. Bairamov and D.A. Aliev. 1992. Functional organization of carbonic anhydrase in higher plants. Plant Physiol., 39: 537-544.

Hafeez, B., Y.M. Khanif and M. Saleem. 2013. Role of zinc in plant nutrition. A review. Am. J. Exp. Agric. 50(1):374-391.https://doi.org/10.9734/ AJEA/2013/2746

Hambidge, K.M. and N.F. Krebs. 2007. Zinc deficiency: A special challenge. J. Nutr., 137(4): 1101-1110. https://doi.org/10.1093/ jn/137.4.1101

Huang, J., C. Pray and S. Rozelle. 2002. Enhancing the crops to feed the poor. Nature, 418: 678684. https://doi.org/10.1038/nature01015

Hussain, A.M., M. Arshad, Z.A. Zahir and M. Asghar. 2015. Prospects of zinc solubilizing bacteria for enhancing growth of maize. Pak. J. Agric. Sci. 52: 915-922.

Ikenie, J., N. Amusa and V. Obatolu. 2004. Nutrient composition and weight evaluation of some newly developed maize varieties in Nigeria. J. Food Tech. Afr.,7: 27-29. https:// doi.org/10.4314/jfta.v7i1.19315

Jackson, M.L., 1962. Soil chemical analysis. Prentice Hall, Inc., Englwood Cliff, New York, USA.

Kamilova, F., L.V. Kravchenko, A.I. Shaposhnikov, N. Makarovaand and B.J.J. Lugtenberg. 2006. Effects of the tomato pathogen Fusarium oxysporum sp. Radices-lycopersiciand of the biocontrol bacterium pseudomonas fuorescens WCS365 on the composition of organic acids and sugars in tomato root exudate. Mol. Plant Microbe Interact., 19: 1121-1126. https://doi. org/10.1094/MPMI-19-1121

Khalid, A., M. Arshad and Z.A. Zahir. 2004. Screening plant growth promoting rhizobacteria for improving growth and yield of wheat. J. Appl. Microbiol., 96: 473-480. https://doi. org/10.1046/j.1365-2672.2003.02161.x
Khalifa, R.K.H.M., S.H.A. Shaaban and A. Rawia. 2011. Effect of foliar application of zinc sulfate and boric acid on growth, yield and chemical constituents of iris plants. Ozean J. Appl. Sci., 4: 130-144.

Lutts, S., J.M. Kinet and J. Bouharmont. 1995. Changes in plant response to $\mathrm{NaCl}$ during development of rice (Oryza sativa L.) varieties differing in salinity resistance. J. Exp. Bot., 46: 1843-1852. https://doi.org/10.1093/ $\mathrm{jxb} / 46.12 .1843$

Mayer, J.E., 2008. Biofortification of crops to alleviate micronutrient malnutrition. Plant Biol., 11: 1-15. https://doi.org/10.1016/j. pbi.2008.01.007

Moodie, C.D., H.W. Smith and R.A. Mccreery. 1959. Laboratory manual for soil fertility, Department of Agronomy, State College of Washingtion Pullman, Washington, USA. pp. 1-75.

Pakistan Economic Survey, 2018-2019. Highlights of Pakistan Economic Survey Report 20182019. Section agriculture. pp: 12-33.

Palanog, A.D., M.I.C. Calayugan, G.I. DescalsotaEmpleo, A. Amparado, M.A. Inabangan-Asilo, E.C. Arocena, P.C. Sta Cruz, Borromeo, T.H. Lalusin, J.E. Hernandez, C. Acuin, R. Reinke and B.P.M. Swamy. 2019. Zinc and iron nutrition status in the Philippines population and local soils. Front. Nutr., 7(6): 81. https:// doi.org/10.3389/fnut.2019.00081

Prasad, R., Y.S. Shivay and D. Kumar. 2013. Zinc fertilization of cereals for increased production and alleviation of zinc malnutrition in India. Agric. Res., 2(2): 111-118. https://doi. org/10.1007/s40003-013-0064-8

Reed, M.L., D. Graham and P.O. Pergamon. 1980. Carbonic anhydrase in plants: Distribution, properties, and possible physiological functions. In Progress in Phytochemistry (ed. Reinhold, L., Harborne, J.B. and Swain, T.). 7: 47-94.

Rehman, A., M. Yasin, M. Akram and Z.I. Awan. 2002. Response of $Z n$ applied and $N$ sources in calcarious soils. Sci. Vis., 8(1): 100-104.

Sadras, V.O., 2007. Evolutionary aspects of the trade-off between seed size and seed number in crops. Field Crops Res., 100: 125-138. https:// doi.org/10.1016/j.fcr.2006.07.004

Saravanan, S.V., R.S. Sudalayandy and Savariappan. 2003. Assessing in vitro solubilization potential of different zinc solubilizing bacteria (ZSB) 
isolates.Braz.J.Microbiol.,34:121-125.https:// doi.org/10.1590/S1517-83822004000100020

Seadh, S.E., M.I. Abady, A.M. Ghamry and S. Farouk. 2009. Influence of micronutrient application and nitrogen fertilization on wheat yield, quality of grain and seed. J. Biosci., 9(8): $\quad$ 851-858. https://doi.org/10.3923/ jbs.2009.851.858

Shih,F.F.,E.T.Champagne,K.Daigle and Z.Zarins. 1999. Use of enzymes in the processing of protei products from rice bran and rice flour. Nahrung Food, 43: 14-18. https://doi.org/10.1002/ (SICI)1521-3803(19990101)43:1<14::AIDFOOD14>3.0.CO;2-K

Shivay, S.Y., P. Rajendra, K.S. Rajiv and P. Madan. 2015. Relative efficiency of zinc-coated urea and soil and foliar application of zinc sulphate on yield, nitrogen, phosphorous, potassium, zinc and iron biofortification in grains and uptake by basmati rice (Oryza sativa L.). J. Agric. Sci., 7(2): 161-174. https://doi.org/10.5539/jas. v7n2p161

Shivay, Y.S.,D. Kumar and R.Prasad.2008. Relative efficiency of zinc sulfate and zinc oxide-coated urea in rice-wheat cropping system. Commun. Soil Sci. Plant Anal., pp. 23-45.

Singh, J.P., R.E. Karamonas and J.W.B. Stewart. 1986. Phosphorous-induced zinc deficiency in wheat on residual phosphorous plots. Agro. J., 78: 668-675. https://doi.org/10.2134/agronj19 86.00021962007800040023x

Singh, O., S. Kumar and Awanish. 2012. Productivity and profitability of rice as influence by high fertility levels and their residual effect on wheat. Ind. J. Agro., 57(2): 143-147.

Soleymani, A. and M.H. Shahrajabian. 2009. The effects of $\mathrm{Fe}, \mathrm{Mn}$ and $\mathrm{Zn}$ Foliar application on yield, ash and protein percentage of forage sorghum in climatic condition of Esfahan. Int.J. Biol. Sci., 4(3): 12-20. https://doi.org/10.5539/ ijb.v4n3p92

Soltanpour, P.N. and S.M. Workman. 1979. Modification of the $\mathrm{NaHCO}_{3}$ DTPA soil test to omit carbon black. Commun. Soil Sci. Plant Anal., 10: 1411-1420. https://doi. org/10.1080/00103627909366996

Sowokinos, J.R. and D.A. Preston. 1988. Maintenance of potato processing quality producers of selected nutrient contents of some tropical maize production. J. Cereal Sci., 16: 3133.
Steel, R.G.D., J.H. Torrie and D.A. Dickey. 1997. Principles and Procedures of Statistics. Mc Graw Hill Co. Inc. New York.

United Nations Development Programme (UNDP), 2003. Human development report, 2003. The millennium development goals: A compact among nations to end human poverty. New York.

United Nations, 2012. World Population Prospects: The 2010 Revision. Online at http://esa.un.org/ unpd/wpp/Documentation/publications.htm. Accessed on june 1.

US Salinity Lab Staff, 1969. Diagnosis and Improvement of Saline and Alkali Soils. USDA Handbook 60, Washington DC, USA.

Watanabe,F.S.andS.R.Olsen.1965.Testofanascorbic acid method for determining phosphorous in water and $\mathrm{NaHCO} 3$ extracts. Soil Sci. Soc. Am. Proc., 29: 677-678. https://doi.org/10.2136/ sssaj1965.03615995002900060025x

Welch, R.M., 1995. Micronutrient nutrition of plants. Crit. Rev. Plant Sci., 14: 49-82. https:// doi.org/10.1080/07352689509701922

WHO, 2002. World health report, 2002: Reducing risks, promoting healthy life. World health organization, Geneva, Switzerland.

Wolf, B., 1982. The comprehensive system of leaf analysis and its use for diagnosing crop nutrient status. Commun. Soil Sci. Plant Anal., 13: 1035-1059. https://doi. org/10.1080/00103628209367332

Yu, X., X. Liu, T.H. Zhu, G.H. Liu and C. Mao. 2011. Isolation and characterization of phosphate solubilizing bacteria from walnut and their effect on the growth and phosphorous mobilization. Biol. Fertil. Soils, 47: 437-444. https://doi.org/10.1007/s00374-011-0548-2

Zhang, Y.Q. Y.X. Sun, Y.L. Ye, M.R. Karim, Y.F. Xue, P. Yan, Q.F. Meng, Z.L. Cui, I. Cakmak, F.S. Zhang and C.Q. Zou. 2011. Zinc biofortification of wheat through fertilizer applications in different locations of China. Field Crops Res., 125: 1-7. https://doi. org/10.1016/j.fcr.2011.08.003

Zhao, F.J., Y.H. Su, S.J. Dunham, M. Rukszegi, Z. Bedo, S.P. McGrath and P.R. Shewry. 2009. Variation in mineral micronutrient concentrations in grain of wheat lines of diverse origin. J. Cereal Sci., 49: 290-295. https://doi. org/10.1016/j.jcs.2008.11.007 